Article

\title{
Public Support for Higher Taxes on the Wealthy: California's Proposition 30
}

\author{
Caroline J. Tolbert ${ }^{1}$, Christopher Witko ${ }^{2, *}$ and Cary Wolbers ${ }^{3}$ \\ ${ }^{1}$ Department of Political Science, University of Iowa, lowa City, IA 52242, USA; E-Mail: caroline-tolbert@uiowa.edu \\ 2 School of Public Policy, Pennsylvania State University, University Park, PA 16802, USA; E-Mail: witko@psu.edu \\ 3 Department of Political Science, University of Nebraska, Lincoln, NE 68588, USA; E-Mail: cwolbers@huskers.unl.edu \\ * Corresponding author
}

Submitted: 15 December 2018 | Accepted: 21 March 2019 | Published: 27 June 2019

\begin{abstract}
It has long been argued that growing inequality would lead to growing demands for redistribution, especially from less affluent individuals who would benefit most from redistribution. Yet, in many countries we have not seen tax increases and even when ballot initiatives allow individuals to directly vote to raise taxes on the wealthy they decline to do so. This raises the question of how economic self-interest shapes voting on tax proposals, and what factors may weaken the links between economic self-interest and tax policy preferences. In the U.S. context partisanship is a factor that has a major influence on attitudes about taxation. To explore how self-interest sometimes overcomes partisanship we take advantage of competing initiatives that were simultaneously on the ballot in California in 2012. California's Proposition 30, a successful 2012 initiative, significantly increased taxes on the wealthy. By comparing voting on Proposition 30 to voting on Proposition 38, which would have raised taxes on nearly everyone, we observe that when tax hikes are focused only on the wealthy a substantial number of lower income Republicans (i.e., conservatives) defect from their party position opposing taxation. We identify these low-income Republicans as "populists." Lower income Republicans are also less supportive of income tax increases on the lower and middle classes, and are more sensitive to income tax increases than sales tax increases. We argue that economic self-interest causes heterogeneity within the parties in terms of attitudes toward tax increases.
\end{abstract}

\section{Keywords}

California; direct democracy; economic self-interest; inequality; partisanship; Proposition 30; redistribution; taxes; voting; wealth

\section{Issue}

This article is part of the issue "The Politics, Promise and Peril of Direct Democracy", edited by "Todd Donovan (Western Washington University, USA).

(C) 2019 by the authors; licensee Cogitatio (Lisbon, Portugal). This article is licensed under a Creative Commons Attribution 4.0 International License (CC BY).

\section{Introduction}

Conflict over redistribution has long been one of the main political fault lines in Western democracies. Political economy models predict that as inequality grows the public, and especially the less affluent, will clamor for more redistribution (Meltzer \& Richard, 1981). If this prediction is accurate, we should see major increases in redistribution in the U.S., where inequality has grown more and is higher than in almost any other affluent democracy. In the U.S. the top $1 \%$ of the population own about $38 \%$ of the all privately held wealth according to federal tax data; the New York Times (Kristof, 2014) reports the richest $1 \%$ now owns more than the bottom $90 \%$ of the population (Piketty, 2014; see also Gilens, 2012; Volscho \& Kelly, 2012). Surveys in the U.S. consistently find that two-thirds of Americans believe that the gap between the rich and everyone else has increased over the last decade, and this view is shared by majorities across nearly all groups in the public, including 61\% of Republicans (Pew Research Center, 2017). Not surprisingly, then, consistent with political economy mod- 
els, Americans express high levels of support for increasing taxes on the wealthy (Dutton, 2012; Roberts, Hite, \& Bradley, 1994; Yglesias, 2019). Yet, over the last few decades we have also seen the public support large tax cuts for the wealthy (Bartels, 2005) and sometimes even when the public has the opportunity to increase taxes on the wealthy by voting on ballot initiatives they decline to do so (Franko, Tolbert, \& Witko, 2013). Why do abstract preferences for redistribution not always translate into support for specific redistributive tax policies? We investigate how economic self-interest, partisanship and the design of specific tax policies combine to shape support for tax increasing ballot initiatives.

Why the public sometimes supports redistributive tax increases but at other times declines to do so is an important question that has been examined in numerous studies (Alesina \& Angeletos, 2005; Ballard-Rosa, Martin, \& Scheve, 2017; Boudreau \& MacKenzie, 2018; Heinemann \& Hennighausen, 2015; Meltzer \& Richard, 1981; Tuxhorn, D'Attoma, \& Steinmo, 2019). Individuals express support for redistribution and higher taxes on the wealthy in the abstract, but this abstract support can disappear in the context of tax policy debates in real world politics (Bartels, 2005; Franko et al., 2013; Franko \& Witko, 2017). One reason is that individuals often fail to link their economic self-interest to congruent positions in specific tax policy debates (Bartels, 2005). Sometimes this is because people do not understand how tax policies will affect them and others (Slemrod, 2006). But, more fundamentally, political economy models ignore the fact that individuals often have strong ideological and partisan attachments, which in the U.S especially are not always closely tied to income position (Mason, 2018), that predispose them for or against particular types of tax increases (Franko et al., 2013). Left-leaning individuals (Democrats) will tend to support many types of tax increases, while conservatives (Republicans) tend to oppose them. But are there conditions in which individuals are willing to elevate their economic self-interest above a general opposition to high taxes along the lines envisioned by political economy models?

It is difficult to distinguish general opposition to taxation from more self-interested opposition because in many policy debates elites opposing taxes focus on the very existence of any tax increase, rather than the specific incidence of who will pay more, and tax cuts that primarily benefit the wealthy usually include at least a small tax cut for others (Bartels, 2005). By comparing attitudes toward competing tax proposals which place burdens on different segments of the population, we could distinguish self-interested opposition to tax increases from more general opposition. Of course, there are seldom competing tax increase proposals put placed on the ballot for a public vote at any one time. Typically, governments develop and then unveil a single proposal and attempt to enact it.

Thus, scholars have used experimental approaches to examine how varying hypothetical tax burdens shapes support from different individuals (Ballard-Rosa, Martin, \& Scheve, 2017; Boudreau \& MacKenzie, 2018). Of course, the drawback of experimental manipulations of tax policy alternatives is that they are usually not examined in the context of actual political debates and campaigns (but see Boudreau \& MacKenzie, 2018). The same limitation applies to surveys asking respondents for their opinions about taxation in the abstract. Here, we take advantage of competing tax proposals that were actually placed in front of California voters as ballot initiatives in 2012 to examine how the structure of tax policies affects individual support, and specifically how economic self-interest (income) and partisanship combine to shape attitudes about taxation. Proposition 30 would have provided additional revenue for a number of government programs and been funded primarily by an increased income tax on the wealthy-individuals earning more than $\$ 250,000$ a year or couples earning more than $\$ 500,000$-along with a more general across the board sales tax increase. In contrast, Proposition 38 would have achieved similar revenue and spending goals, but been funded primarily by an income tax increase on virtually all Californians, including substantial increases on the middle class. These competing initiatives on the same ballot in the same year allow us to distinguish between individuals who support or oppose tax increases regardless of their specific structure to those who oppose or support tax increases based on whether they are likely to benefit.

Not surprisingly, we observe that Democrats generally support tax increases of any type at high levels, while Republicans generally oppose raising taxes (see Table 1). However, when tax hikes are focused mostly on the wealthy a substantial number of lower income Republicans defect from their party position opposing taxation. Overall, the effect of self-interest varies depending on one's party and the type of tax in question. Lower income Republicans are less supportive of income tax increases on the lower and middle classes than lower income Democrats and are much more sensitive to income tax increases than sales tax increases. This suggests that one reason that taxes have not increased in response to growing income inequality in the U.S. and other countries is that many individuals choose not to support tax increases due to their partisanship and concerns that their own taxes may be increased, rather than any general antipathy to high taxes per se.

\subsection{The Roots of Public Support for Raising Taxes}

Political economy models predict that individuals evaluate tax increases on the basis of their economic selfinterest, i.e., how the tax hike will negatively impact their income and positively impact the benefits they receive from government. There are a number of reasons why this relationship is not always observed in empirical research (Sears \& Citrin, 1982). But one of the key reasons that self-interest is not always associated with individ- 
ual tax policy preferences is that broader values and attitudes shape views toward tax policies. Among the most important factors in the U.S. is partisanship, which can weaken the link between economic self-interest and policy preferences.

\subsubsection{Economic Self-Interest}

The canonical Meltzer and Richard (1981) model of redistributive policy preferences has both macro and microlevel implications. At the macro-level income inequality should spur growing redistribution. The micro-level mechanism is that preferences for redistribution reflect individual choices, with individuals lower in the income distribution more likely to support tax increases on the wealthy because it is in their economic self-interest. If a tax increase targets the wealthy, the poor or middle class will not pay the tax, but they can benefit from the government programs that are funded with that tax increase.

While the logic of the Meltzer-Richard model (1981) is intuitive, there are a number of reasons why individuals may not support tax increases on the wealthy, even if they are relatively poor. First, if they believe that individuals achieve their wealth through hard work, they are less likely to support tax increases on the wealthy, compared to if they believe it was by luck or birth (Alesina \& Angeletos, 2005; Henninghausen \& Heinemann, 2015). Second, they might not support higher taxes on the wealthy if they believe that they will someday be wealthy or financially better off (Alesina, Stantcheva, \& Teso, 2018; Benabou \& Ok, 2001; Piketty, 1995). They may also be against redistribution if they do not trust that the government will do the right thing with the tax revenue raised (McCall \& Kenworthy, 2009; Tuxhorn et al., 2019). It may also be that individual economic policy preferences primarily reflect broader sociotropic (economic or cultural) concerns, and not economic self-interest (Sides \& Citrin, 2007).

Nevertheless, a substantial amount of research in the U.S., which is the focus of the empirical analysis here, indicates that lower income individuals do indeed have more left-leaning views on broad redistributive taxation and spending issues than affluent and very wealthy individuals (Bartels, 2005; Kelly \& Enns, 2010; Kelly \& Witko, 2012; Page, Bartels, \& Seawright, 2013). One reason that observed tax rates have not responded to growing inequality in the U.S. may be that individuals with influence in the policy process have different views about taxes than the mass public. For instance, research finds that across a range of issues lawmakers and their staff perceive constituency opinion to be more conservative than it actually is and legislators are more responsive to the wealthy and well-organized interests than average taxpayers (Bartels, 2008; Broockman \& Skovron, 2018; Enns, Kelly, Morgan, Volscho, \& Witko, 2014; Gilens, 2012; Hertel-Fernandez, Mildenberger, \& Stokes, 2019; Witko, 2017).

However, in the context of specific tax policy debates we often fail to observe individuals preferring tax poli- cies that are consistent with their own economic selfinterest. For instance, in an analysis of support for the 2001 Bush tax cuts, Bartels $(2005,2008)$ found that income was not a very important predictor of tax policy preferences, even though these tax cuts would disproportionately benefit the wealthy.

Research shows that the initiative can lead to the closer alignment of public preferences and public policy (Franko \& Witko, 2017; Gerber, 1999; Kogan, 2016; Matsusaka, 2004), which can lead to higher taxes on the wealthy. For example, research on German local governments shows that where individuals can directly vote on taxes, taxes are higher and they also have a much narrower base (Asatryan, Baskaran, \& Heinemann, 2017), suggesting that individuals like taxes, as long as others are paying them. Research finds that lower income individuals were more likely to support a ballot initiative that would have increased taxes on the wealthy in Washington state in the U.S (Franko et al., 2013). However, it is notable that, despite the fact that the vast majority of voters would not have paid any taxes, enough people opposed the initiative that is was not passed. What can explain why even relatively less affluent individuals that express abstract support for increasing taxes on the wealthy in surveys would not vote to do so when given the opportunity? Unlike surveys, once tax proposals leave the realm of abstract survey questions or experimental manipulations and enter into actual political debates competing partisan elites attempt to foment hostility or support for tax increases.

\subsubsection{Partisanship}

Partisanship is a key factor driving support for a variety of policies (Abramowitz, 2018; Green, Palmquist, \& Schickler, 2004; Lenz, 2009). Though ballot proposals are generally nonpartisan, party elites take positions on proposals and thus partisanship is important in voter decision making on ballot measures (Bowler \& Donovan, 1998; Lupia, 1994). If individuals choose political parties as a result of their economic position, then partisanship would strengthen the relationship between economic self-interest and voting on tax policy initiatives. While low-income individuals are more likely to identify as Democrats (Kelly \& Witko, 2012), many affluent individuals support the Democratic Party, and many poorer individuals support the Republican Party.

According to recent important research by Mason (2018) partisanship in the contemporary U.S. is not based mostly on rational calculations about which party best advances one's interests, but is more akin to rooting for a sports team. A great deal of research shows that voters are influenced by the positions of elites within their parties, rather than or in addition to joining parties on the basis of their preexisting policy preferences (Broockman \& Butler, 2017; Lenz, 2009). Even controlling for past issue preferences, party affiliation shapes the subsequent issue positions of partisan voters (Lenz, 
2009). Because anti-tax rhetoric and ideological positiontaking is so central to the modern Republican Party's economic policy agenda (Grossman \& Hopkins, 2016), Republican identifiers are heavily predisposed to oppose taxation, particularly when such proposals are framed by elite rhetoric.

In one of the highest profile tax policy changes in the U.S. in recent decades, Lupia, Levine, Menning and Sin (2007) argue that partisanship explains support or opposition to the 2001 Bush tax cuts better than self-interest, information or other factors. These same patterns are evident in voting on statewide ballot measures. In addition to finding that low-income voters were more supportive, Franko et al. (2013) find that party had the largest effect on support for a 2010 ballot initiative in Washington state that would have significantly raised taxes on the wealthy. State ballot contests are officially non-partisan, but partisanship is nevertheless a critical factor in voting on initiatives over time (Bowler \& Donovan, 1998; Branton, 2003; Smith \& Tolbert, 2001). Indeed, because voters are responsive to cues from partisan elites (Bowler \& Donovan, 1998, 2004) and organized interests that are typically associated with one of the parties, individual partisanship is the most important predictor of voting behavior in initiative elections in the American states over time (Branton, 2003).

But most individuals do not have a consistent liberal or conservative set of policy preferences (Campbell, Converse, Miller, \& Stokes, 1960). Research by Claassen, Tucker and Smith (2013) implies that even some selfproclaimed ideologues may not be able to correctly sort into the liberal or conservative party because they do not even know what liberal and conservative mean. Ellis and Stimson (2012) show that many voters who identify as conservatives (and thus are mostly Republicans) actually hold liberal economic and fiscal policy preferences. Thus, when individuals describe themselves as liberal or conservative many are not referring to support for government spending or types of taxation regimes but a social identity based on demographic factors, region or religion (see Mason, 2018). Ellis and Stimson (2012) refer to voters that identify as conservatives but have liberal attitudes toward economic and fiscal policy as conservative "populists," and we adopt this narrow definition of the term here. This means that even though Republicans are predisposed to oppose tax increases due to their partisanship, this opposition is not completely fixed. Under some circumstance, self-interest may trump partisanship.

Similarly, wealthy Democrats may sometimes prefer to not raise taxes, particularly if they are the intended targets of tax increases. However, because the number of very wealthy voters is small, these individuals do not generally have the ability to determine outcomes for ballot propositions, and they appear in very small numbers in conventional surveys. Thus, we focus more on how lowincome Republicans may shift their opposition to taxes depending on the structure of tax increases. We argue that economic self-interest causes heterogeneity within the parties in terms of attitudes toward tax increases.

\section{Policy Design: The Structure of Tax Increases}

One reason that arguments against taxes can be effective even among individuals who might otherwise support them is that tax policy tends to be relatively complicated (compared to say, abortion or gay marriage). Indeed, some research shows that misunderstandings of tax policy can contribute to support for regressive tax increases, even among the poor (Slemrod, 2006). In many tax policy debates it is difficult to tell ahead of time just who the winners and losers are.

Tax increases may vary along a number of dimensions including who pays the tax (e.g., the wealthy, all income earners), the type of tax (e.g., sales v. income), the amount of the tax increase (and revenue raised), and whether the tax increase is permanent or temporary. While for many low-income taxpayers the payroll and sales tax actually are more of a financial burden, the income tax is without question politically the most salient tax for American taxpayers; taxpayers must go through the process of completing an annual tax return form which clearly indicates the amount owed in taxes. In the states, the sales tax is generally the largest or second largest (after the income tax) source of revenue for state governments. But there may be less opposition to sales taxes because they are viewed as a small percentage of purchases and the costs are hidden when individuals make purchases.

Finally, who pays the tax may influence the support for the tax increase. In a democracy where majorities to some extent rule, tax increases targeted at small numbers of individuals may have more support among citizens. In contrast, more broad-based tax increases should have less support among the public, especially among individuals that are already predisposed to be against taxes. Because the wealthy are both a small minority and have substantial resources to put into public coffers, they are likely to be an attractive target for tax increases, potentially even for those that do not generally like the idea of increasing taxes. For instance, Asatryan et al. (2017) find that where Germans had the ability to vote directly on local taxes they were higher and more focused on businesses. This suggests, intuitively enough, that individuals like to tax others.

\section{Empirical Expectations}

Based on the foregoing discussion we expect Democrats will, of course, be more likely to favor tax increases than Republicans, and that partisanship will be a larger factor in determining voting on tax policy preferences. However, where the incidence of salient (income) taxes very clearly falls on others, individuals that might generally oppose taxation, Republicans, will be more likely to support the tax increase. In our empirical analysis we leverage competing tax proposals to examine this possibility. 
Table 1. Voter support for redistributive ballot measures by party.

\begin{tabular}{|c|c|c|c|c|c|}
\hline & $\mathrm{N}$ & $\begin{array}{l}\text { Support } \\
\text { Proposition } 30\end{array}$ & $\begin{array}{l}\text { Support for } \\
\text { Proposition } 38\end{array}$ & Support Neither & Support Both \\
\hline Democrat & 271 & 0.793 & 0.645 & 0.158 & 0.597 \\
\hline Independent & 368 & 0.570 & 0.440 & 0.375 & 0.385 \\
\hline Republican & 317 & 0.293 & 0.274 & 0.605 & 0.173 \\
\hline Low Income & 240 & 0.658 & 0.571 & 0.241 & 0.500 \\
\hline Median Income & 531 & 0.480 & 0.392 & 0.441 & 0.313 \\
\hline High Income & 201 & 0.557 & 0.428 & 0.398 & 0.383 \\
\hline Taxes Burden Not Too High & 657 & 0.642 & 0.519 & 0.292 & 0.454 \\
\hline Taxes Burden Too High & 315 & 0.327 & 0.286 & 0.594 & 0.206 \\
\hline
\end{tabular}

\section{Proposition 30}

California state public employee unions and the California Democratic Party gathered signatures to place an initiative before voters which would prevent proposed large reductions in spending on government programs. The main provisions of Proposition 30 were to increase marginal tax rates for seven years by $1 \%$ for income between $250-300 \mathrm{~K}, 2 \%$ for income between $300-500 \mathrm{~K}$ and $3 \%$ for income over $500 \mathrm{~K}$ (twice these amounts for couples). It also increased the state sales tax by a $1 / 4$ cent for four years and used the revenue to fund public safety, $\mathrm{K}-12$ education (primary and secondary education) and community colleges (i.e., two-year colleges). Proponents argued that Proposition 30 would provide funding for California's public education, help balance the state's budget, and prevent cuts to public safety programs (KCET, 2012). The initiative proposed a tax increase of approximately $30 \%$ on earnings above $\$ 1$ million, a substantial increase by any measure. Though there was also a (regressive) sales tax increase as part of the bill, the more salient aspect of Proposition $\mathbf{3 0}$ was the potential income tax increase because the sales tax increase was very small and was to last a shorter period of time.

Proposition 30 was opposed by the Small Business Action Committee and the Howard Jarvis Taxpayers Association, the same organization that sponsored Proposition 13 three decades earlier (Sears \& Citrin, 1982). Big business groups (like the California Chamber of Commerce) that often oppose tax increases stayed neutral and some large firms actually endorsed the measure, including Bank of America, AT\&T, and Kaiser Permanente, citing the need to invest in the state's schools to produce an educated workforce (Buchanan, 2012).

\section{Proposition 38}

A rival ballot measure, Proposition 38, was intended to increase personal income tax rates on annual earnings over $\$ 7,316$ using a sliding scale from .4\% for lowest individual earners to $2.2 \%$ for individuals earning over $\$ 2.5$ million, for twelve years. The funds were targeted for early childhood programs and K-12 (primary and secondary) educa- tion. These competing initiatives are similar in that they both raise taxes and they provide additional revenue for public programs, especially education. However, Proposition 38 would have raised income taxes on the lower and middle classes, and by a substantial amount. Families with incomes of $\$ 60,000$ would have seen their top marginal tax rate increase from 6.0 to $7.1 \%$ with Proposition 38 , but the income tax would not increase at all under Proposition 30 (Legislative Analysts Office, 2012). The two ballot initiatives would have both increased funding of government programs from the baseline but with different income tax structures or policy design.

Of course, these treatments are not perfect because there are some differences between the two initiatives. The time horizon of the income tax increase was longer for Proposition 38 (12 years) compared to Proposition 30 (7 years). Proposition 30 would increase the sales tax by a $1 / 4$ cent for four years while Proposition 38 did not change the sale tax. Democratic Governor Jerry Brown was a strong and vocal proponent of Proposition 30, which should have offered an important partisan cue to voters; gubernatorial endorsements have influenced other salient initiative contests (Nicholson, 2005; Tolbert \& Hero, 1996). Proposition 38 and its campaign were funded by Pasadena civil rights attorney Molly Munger, daughter of Berkshire Hathaway executive Charles Munger. Munger's proposal for how to fund public schools competed with Governor Jerry Brown's favored policy. The public was familiar with the arguments for and against Proposition 30 and Proposition 38 with well-funded add campaigns (Burnett, 2013). Proposition 30 's supporters raised over $\$ 72$ million dollars to the cause, while opponents spent over $\$ 76$ million, which when combined adds up to almost $\$ 4$ per voter; this is more than what was spent per voter in recent presidential elections in the state (followthemoney.org). Proposition 30 passed with $55.4 \%$ of the vote, and Proposition 38 was defeated, receiving $28.7 \%$ yes votes.

Because both measures were on the ballot at the same time, individuals were in the unique position of directly comparing competing tax policy proposals. Thus, the differences in the proposals were very clear and very salient compared to other tax policy debates. 


\section{Analysis}

\subsection{Survey Data and Coding}

The analysis employs data from the 2012 California Field Poll, which is a random sample computer-assisted telephone survey carried out by the Field Research Corporation. In regard to Proposition 30, the survey presented respondents with the following information:

Proposition 30 is the Temporary Taxes to Fund Education, Guaranteed Local Public Safety Funding initiative. It increases taxes on earnings over $\$ 250,000$ dollars for seven years and sales taxes by a $1 / 4$ cent for four years, to fund schools and guarantees public safety realignment funding. Fiscal impact: Increased state tax revenues through 2018-2019, averaging about 6 billion dollars annually over the next few years. Revenues available for funding state budget. In 2012-2013, planned spending reductions, primarily to education programs, would not occur. (D-Lab, n.d.)

Respondents were then asked whether they would support or oppose Proposition 30. In the following analyses, this question serves as the dependent variable, where 1 indicates support for Proposition 30, and 0 indicates opposition or lack of an opinion. By preceding the question with an informational paragraph, we are able to determine support for Proposition $\mathbf{3 0}$ as if everyone had been paying enough attention to the policy debate to understand the content of the proposed initiatives. Given the campaign spending and press coverage, there was presumably a high degree of familiarity with Proposition 30's basic provisions in the broader population. Similar coding and question wording was used to measure support for the counter initiative, Proposition 38 (see the 2012 California Field Poll). Because the outcome variables are binary, logistic regression is used in the statistical analysis.

The survey included separate questions for party registration and ideology, but since most theorizing is about the effects of party, we consider this in the analysis. The sample used in the analysis included partisans and independents. Party was coded on an ordinal 3-point scale where Democrat $=1$, independent $=2$ and Republican $=3$. We use this ordinal measure and also estimate models using separate dichotomous variables for whether the respondent is a Democrat (coded 1) or Republican (coded 1), with independents (coded 0) as the reference group to ensure the results don't change based on the measurement of party.

To test the unenlightened self-interest hypothesis, we use a variable capturing respondents' perceptions of their local and state tax burden, where 1 indicated that the respondent believed they were paying "more than you should," and 0 indicted respondents who believed they are paying "just the right amount" or "less than you should."
We include a variable measuring respondents' income to test the economic self-interest hypothesis. It is unclear exactly how many of the survey's respondents would directly feel the impact of Proposition 30 because the field poll asked respondents to indicate which of six income categories they identified with, the highest of which was over $\$ 100,000$. Thus, we cannot know with certainty whether anyone in the sample earned above $\$ 250,000$ per year and is therefore subject to the tax. Higher income earners may have a more realistic possibility of paying the tax at some point in the future, so we test income through the use of a continuous ordinal income variable (for the six categories) and binary variables.

We alternatively measure income with binary variables for low (coded 1, all other 0 ) and high income respondents (coded 1 , all others 0 ). For the models using the binary predictors a variable was created to indicate respondents who do not own a home and who earn under $\$ 60,000$, which is the category containing the median family income in California since those at or below the median should prefer higher taxes on the wealthy according to economic theory (Meltzer \& Richard, 1981). We only include low-income non-homeowners in order to remove retirees who have some material wealth in the form of a home from being considered low-income since a home in California tends to represent a considerable source of wealth. A binary variable was also created to indicate "high income" respondents who earned $\$ 100,000$ or more annually, with respondents who indicated earning between $\$ 60,000$ and $\$ 100,000$ annually as the reference category. Interaction terms are used to measure the conditional effects of economic self-interest and partisanship.

A series of statistical controls include-age (measured in years), gender (male), education, marital status (married $=1$ ), homeownership (equal to 1 if respondent is a homeowner; 0 otherwise) and a series of dummies to control for race/ethnicity (Hispanic, black or Asian, with white as the reference category). Because the debate hinged on whether people wanted to spend more money on government services we also include two dummy variables that measure whether respondents thought that government services have gotten better in recent years, or worse in recent years (with no change as the baseline or reference category).

Because the dependent variable is binary we estimate logistic regressions with robust standard errors clustered by county, since respondents in different areas may have been exposed to different levels of media and campaign effects. We begin by estimating the additive models and then estimate interaction models.

\section{Results}

Since Proposition 30 was enacted while Proposition 38 failed we can conclude that taxpayers are not particularly concerned about relatively modest sales tax increases, 
but are more sensitive to income tax increases. Whereas Proposition 38 would have raised income taxes on nearly everyone, Proposition 30 only targeted the wealthy. But Proposition 30 also had a shorter time horizon, seven years instead of 12 , which may have affected overall support. Taken together, this would suggest that short-term sales tax increases are an effective way for governments to raise revenue without too much public opposition.

Table 1 provides frequencies of support for both initiatives broken down by party, perceptions of tax burdens and personal income. While patterns of support for Proposition 30 and 38 are similar across our three explanatory variables, it is interesting that for Democrats and independents there was a big drop off in support for Proposition 38 compared to Proposition 30, but less so for Republicans. Democratic Governor Jerry Brown's strong endorsement of Proposition 30 likely provided a salient cue to voters. While support for Proposition 30 was higher across the board than for Proposition 38, it is interesting that high income voters were $13 \%$ more likely to favor tax increases on the wealthy than across the board tax increases, while the gap was $9 \%$ for low and middle income respondents.

Table 2 presents the results of the multivariate logistic regression predicting support for Proposition 30, varying the respondent's partisanship (ordinal measure vs a series of dummy variables) and household income (measured as an ordinal variable and with binary variables for low-income and high income with middle income as the reference category). Regardless of how the variables were measured, we find that Republicans were significantly more likely to oppose raising taxes on the wealthy. Similarly, individuals who felt their state and local text burdens were too high are significantly more likely to oppose the measure, providing evidence for the unenlightened self-interest hypothesis.
When personal income is measured by the ordinal variable (columns 1 and 3 ) the coefficient is not significant, but the binary variable for lower income is positive and statistically significant, indicating that lower income citizens are significantly more likely to favor raising taxes on the wealthy compared to those with middle income or the wealthy. These results are reported in columns 2 and 4 . We find some support for that partisanship, selfinterest and unenlightened self-interest (opinions about one's own tax burden) mattered.

To understand the substantive effect of these relationships we generate predicted probabilities from the coefficients in Table 2. We measure the change in support for the ballot measure when moving from being a Republican to a Democrat, from being high income to low-income, and from thinking your taxes are too high to thinking your taxes are not too high, while holding all other variables constant at their mean. Figure 1 reports the change in probabilities (first differences) for these three statistically significant variables based on the model in column 2 of Table 2. Moving from stating one's tax burden is "too high" to "not too high or just right," changes the probability of favoring the ballot measure by .28 probability, all else equal. This large substantive effect is the effect of "unenlightened self-interest," consistent with previous research re the Bush 2001 taxes (Bartels, 2008). Moving from a high income respondent to a lowincome respondent increases the probability of raising taxes on the wealthy by .075 . This is the direct effect of economic self-interest. But partisanship is more important than self-interest in terms of a direct substantive effect. Moving from a Republican to a Democrat, results in a .44 change in the probability of supporting taxes on the rich, controlling for other factors. Thus, partisanship and unenlightened self-interest appear to have the largest direct substantive effects, with party the most important.

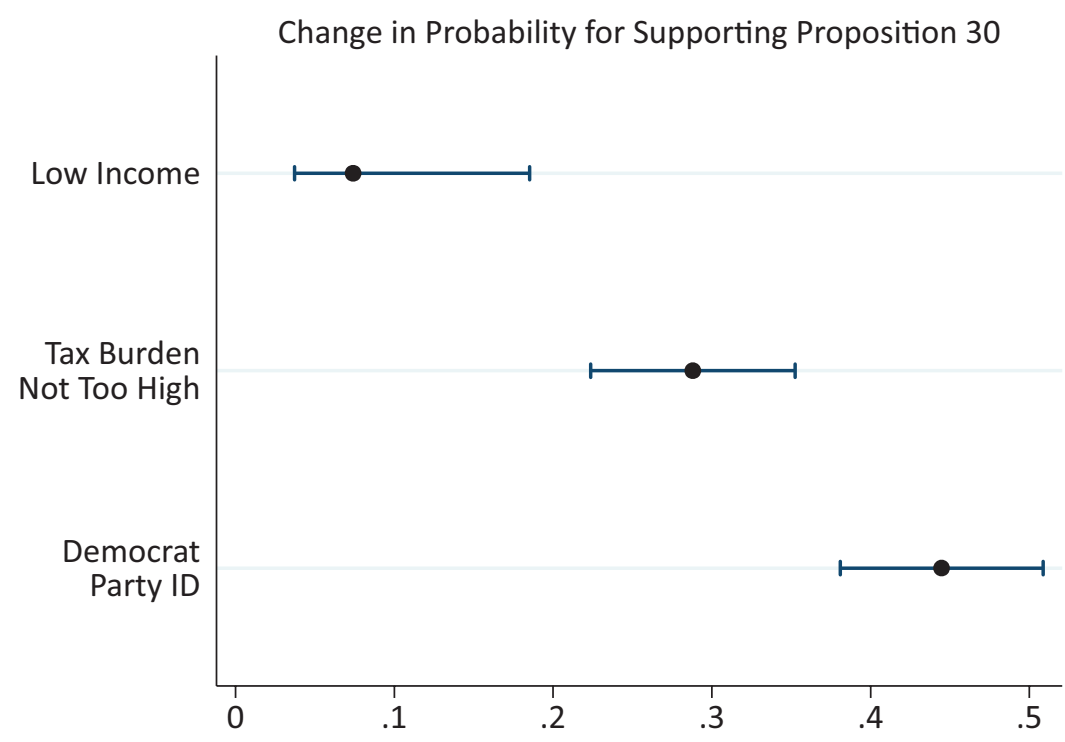

Figure 1. Change (first difference) in the probability of supporting tax increases on the wealthy (from Table 2 column 2 ). 


\subsection{Economic Self-Interest and Party}

Table 3 replicates the model in column 2 of Table 2 but includes interaction terms for partisanship with tax burden attitudes, and an interaction of partisanship with income. While the interaction term for high income multiplied by partisanship is not statistically significant (column 1), the interaction term for low-income respondents with partisanship (column 2) is positive and statistically significant. This suggests economic self-interest is moderating the effect of party. The interaction effect for attitudes about tax burdens and partisanship is negatively signed in column 3 but not statistically significant. However, the base term for party is statistically significant. Jaccard and Turrisi (2003) argue that if either of the base terms in an interaction equation are statistically significant, the interaction model is statistically significant, even if the interaction term itself is not. We thus graph the predicted probabilities for this interaction model as well.

Predicted probabilities are presented in Figures 2 (coefficients from Table 3 column 3 ) and Figure 3 (Table 3 column 2). Figure 2 shows that if the respondent thinks they pay the right amount in state and local taxes a majority of Democrats and independents favor raising taxes on the wealthy (holding other factors constant), but support drops among Republicans, even for those who don't think they pay too much in taxes. Among respondents who believe their tax burdens are too high, a majority of both independents and Republicans opposed the ballot measure. For Republicans, who are predisposed to be

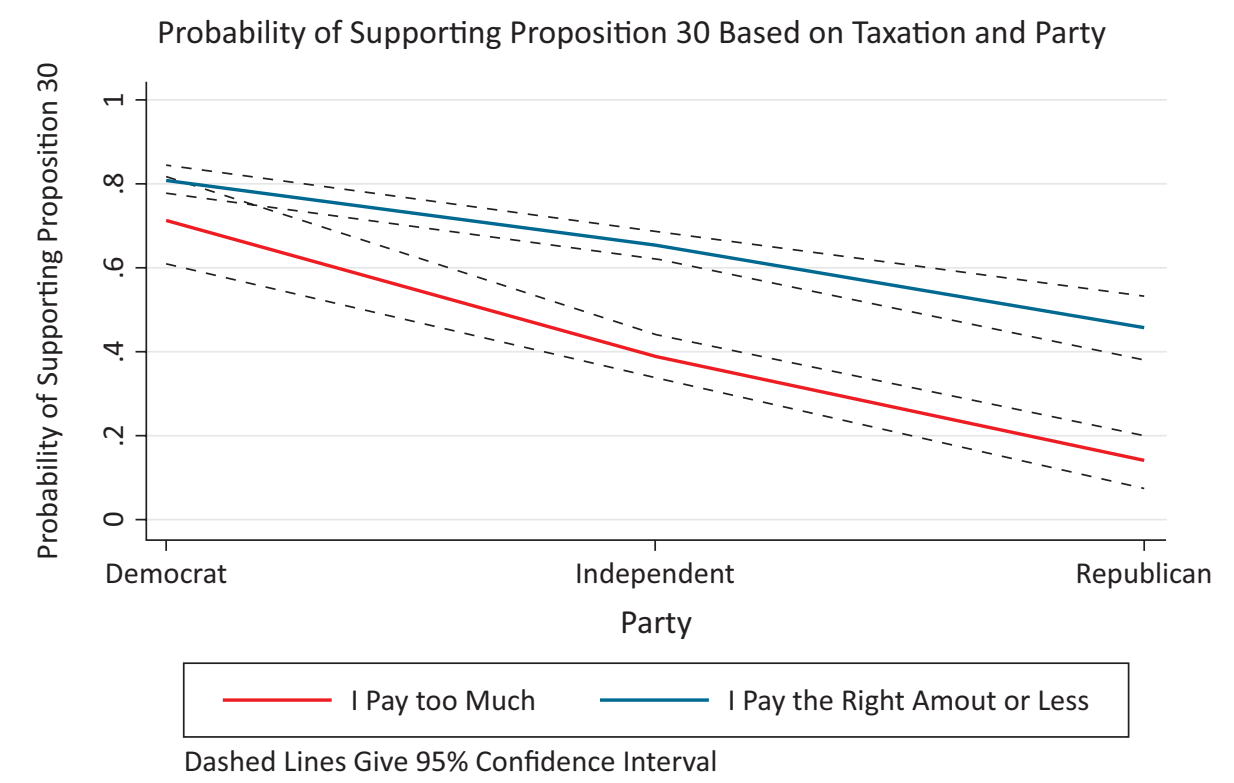

(a)

Support for Proposition 38 Based on Income and Party

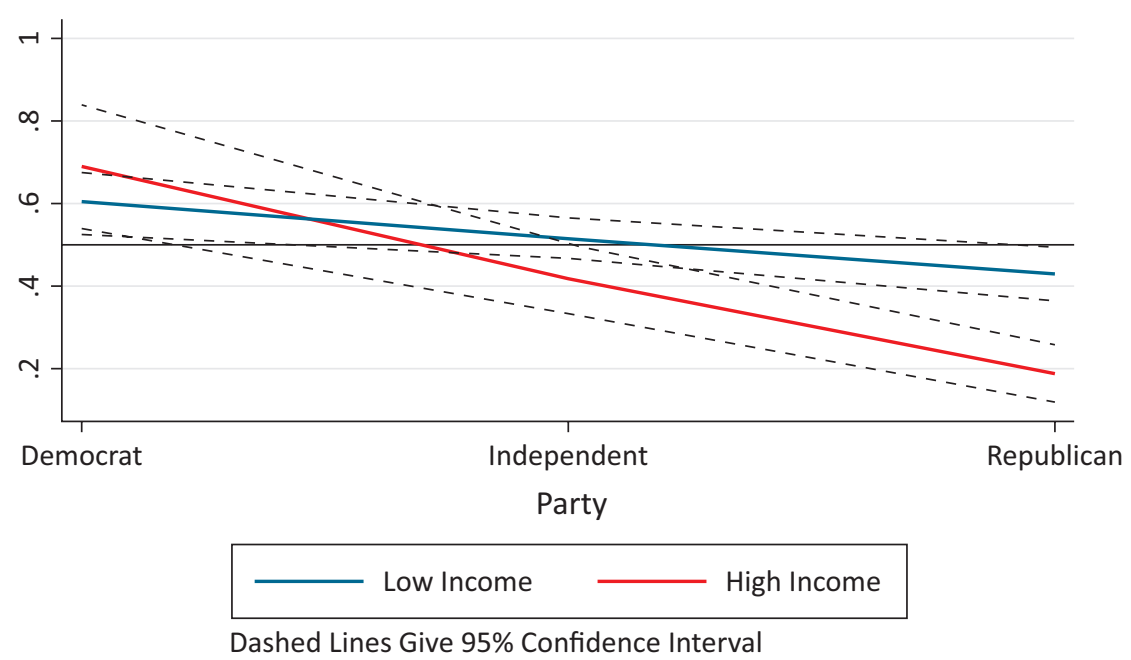

(b)

Figure 2. Conditional effect of tax burden and party identification on the probability of favoring tax increases for (a) on the wealthy (b) for everyone. 
receptive to anti-tax messages, the gap between those who think their tax burden was too high and those that think their tax burden is not too high is very large, estimated to be a difference of about 30 percentage points. Thus, partisan affiliation amplified views about tax burdens for Republicans, reducing support, while making it a less important consideration for Democrats.

Figure 3 reports the results of the interaction between partisanship and low-income (incomes at or below the median in the state). For Republicans, increasing income resulted in a decreased probability of supporting the tax increase on the rich, while a majority of lowincome Republicans favored it. For Democrats, the effect was the opposite-higher income voters were actually more supportive of Proposition 30 , though the differ- ences were fairly modest and not statistically significant. Here, enough lower income Republicans and independents supported the proposal to enact it with the overwhelming support of Democrats. Lower income "populist" Republicans defected from their party's position in supporting higher taxes on the wealthy.

\subsection{Counter Initiative: Proposition 38}

Tables 1-3 replicate the models above, comparing support for Proposition 30 to Proposition 38. The same pattern of low-income Republicans favoring the tax increase is evident but to a much lower degree (see Figures 3B). While low-income people are more likely to favor both tax increases, the size of the coefficient for

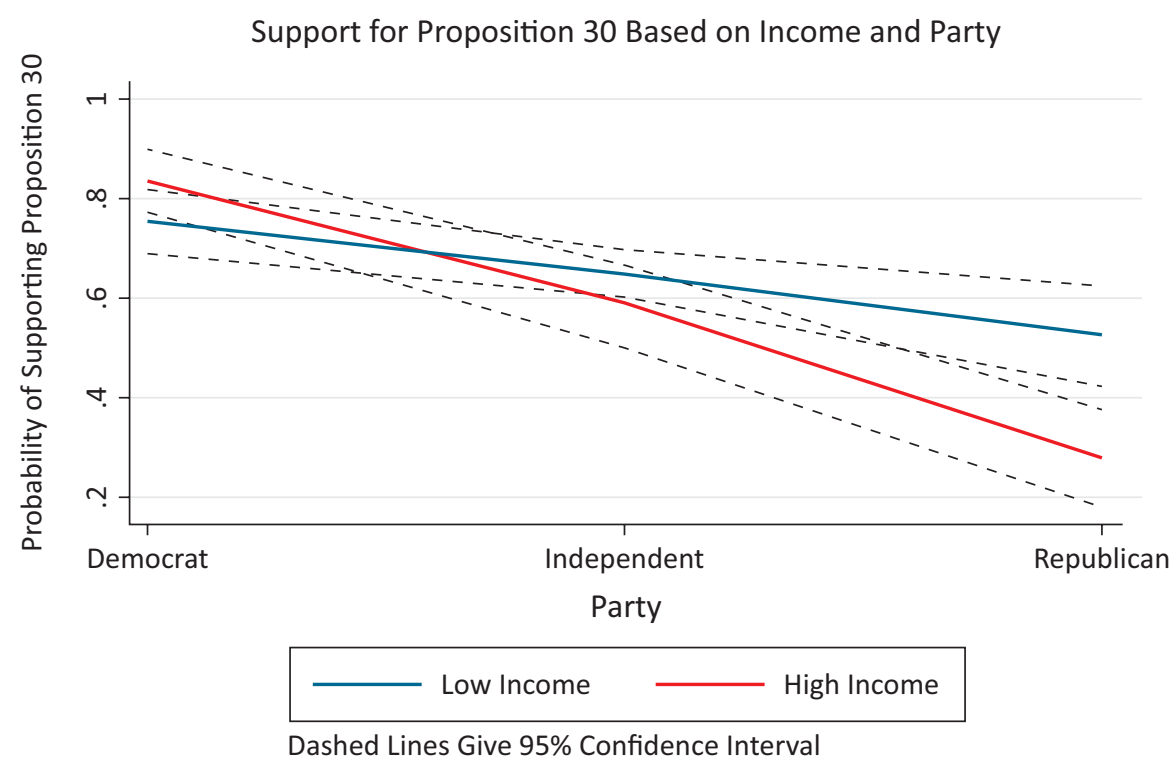

(a)

Support for Proposition 38 Based on Taxation and Party

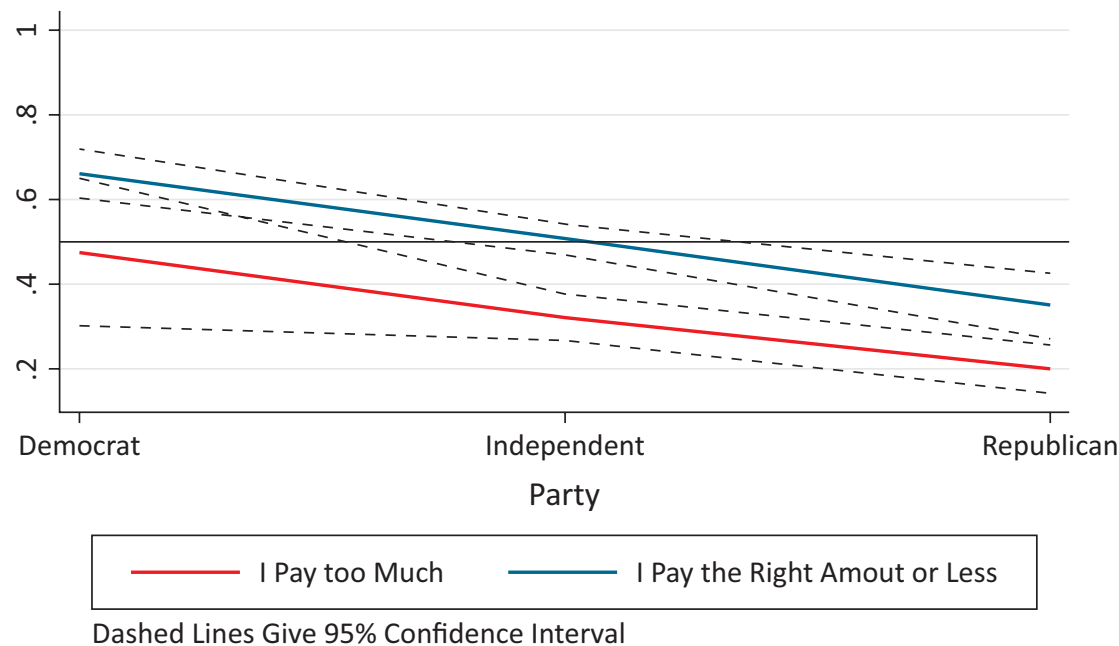

(b)

Figure 3. Conditional effect of tax burden and partisanship on the probability of favoring tax increases for (a) on the wealthy (b) for everyone. 
Table 2. Predicting Voter Support for Proposition 30

\begin{tabular}{|c|c|c|c|c|}
\hline & \multicolumn{4}{|c|}{ Dependent variable: } \\
\hline & \multicolumn{4}{|c|}{ Yes on Proposition 30} \\
\hline & (1) & $(2)$ & (3) & (4) \\
\hline Partisanship (Republican) & $\begin{array}{c}-0.970 * * * \\
(0.081)\end{array}$ & $\begin{array}{c}-0.973 * * * \\
(0.082)\end{array}$ & & \\
\hline Republican & & & $\begin{array}{c}-0.872^{* * *} \\
(0.200)\end{array}$ & $\begin{array}{c}-0.870^{* * *} \\
(0.195)\end{array}$ \\
\hline Democrat & & & $\begin{array}{l}1.087^{* * *} \\
(0.200)\end{array}$ & $\begin{array}{l}1.095^{* * *} \\
(0.197)\end{array}$ \\
\hline Perceive Tax Burden Too High & $\begin{array}{c}-1.179 * * * \\
(0.140)\end{array}$ & $\begin{array}{c}-1.186 * * * \\
(0.143)\end{array}$ & $\begin{array}{c}-1.184 * * * \\
(0.136)\end{array}$ & $\begin{array}{l}-1.191^{* * *} \\
(0.139)\end{array}$ \\
\hline Income & $\begin{array}{c}0.015 \\
(0.050)\end{array}$ & & $\begin{array}{c}0.013 \\
(0.053)\end{array}$ & \\
\hline Income Missing & $\begin{array}{c}-0.112 \\
(0.374)\end{array}$ & $\begin{array}{c}0.034 \\
(0.298)\end{array}$ & $\begin{array}{c}-0.125 \\
(0.383)\end{array}$ & $\begin{array}{c}0.027 \\
(0.300)\end{array}$ \\
\hline Home owner & $\begin{array}{c}-0.401 * * \\
(0.130)\end{array}$ & & $\begin{array}{c}-0.401 * * \\
(0.131)\end{array}$ & \\
\hline High income (above 100K) & & $\begin{array}{c}0.197 \\
(0.184)\end{array}$ & & $\begin{array}{c}0.197 \\
(0.184)\end{array}$ \\
\hline Low income (below 60K) & & $\begin{array}{l}0.506 * * \\
(0.155)\end{array}$ & & $\begin{array}{l}0.510^{* *} \\
(0.157)\end{array}$ \\
\hline Services Worse & $\begin{array}{c}-0.228 \\
(0.139)\end{array}$ & $\begin{array}{c}-0.230 \\
(0.137)\end{array}$ & $\begin{array}{c}-0.232 \\
(0.139)\end{array}$ & $\begin{array}{c}-0.235 \\
(0.136)\end{array}$ \\
\hline Services Better & $\begin{array}{c}0.162 \\
(0.089)\end{array}$ & $\begin{array}{c}-0.159 \\
(0.091)\end{array}$ & $\begin{array}{c}-0.165 \\
(0.090)\end{array}$ & $\begin{array}{c}-0.162 \\
(0.092)\end{array}$ \\
\hline Age & $\begin{array}{c}-0.008^{*} \\
(0.003)\end{array}$ & $\begin{array}{c}-0.009 * * \\
(0.003)\end{array}$ & $\begin{array}{c}-0.008^{*} \\
(0.003)\end{array}$ & $\begin{array}{c}-0.009 * * \\
(0.003)\end{array}$ \\
\hline Education & $\begin{array}{c}0.099 \\
(0.067)\end{array}$ & $\begin{array}{c}0.105 \\
(0.065)\end{array}$ & $\begin{array}{c}0.098 \\
(0.067)\end{array}$ & $\begin{array}{c}0.104 \\
(0.064)\end{array}$ \\
\hline Hispanic & $\begin{array}{c}0.517 \\
(0.296)\end{array}$ & $\begin{array}{c}0.501 \\
(0.285)\end{array}$ & $\begin{array}{c}0.518 \\
(0.292)\end{array}$ & $\begin{array}{c}0.504 \\
(0.280)\end{array}$ \\
\hline African American & $\begin{array}{l}0.612^{* *} \\
(0.237)\end{array}$ & $\begin{array}{c}0.597^{*} \\
(0.239)\end{array}$ & $\begin{array}{l}0.617^{* *} \\
(0.237)\end{array}$ & $\begin{array}{c}0.602^{*} \\
(0.239)\end{array}$ \\
\hline Asian & $\begin{array}{c}0.325 \\
(0.188)\end{array}$ & $\begin{array}{c}0.297 \\
(0.182)\end{array}$ & $\begin{array}{c}0.334 \\
(0.189)\end{array}$ & $\begin{array}{c}0.308 \\
(0.185)\end{array}$ \\
\hline Married & $\begin{array}{c}0.075 \\
(0.152)\end{array}$ & $\begin{array}{c}0.069 \\
(0.156)\end{array}$ & $\begin{array}{c}0.082 \\
(0.150)\end{array}$ & $\begin{array}{c}0.075 \\
(0.153)\end{array}$ \\
\hline Male & $\begin{array}{c}-0.108 \\
(0.110)\end{array}$ & $\begin{array}{c}-0.108 \\
(0.111)\end{array}$ & $\begin{array}{c}-0.113 \\
(0.113)\end{array}$ & $\begin{array}{c}-0.113 \\
(0.114)\end{array}$ \\
\hline Constant & $\begin{array}{l}2.842^{* * *} \\
(0.343)\end{array}$ & $\begin{array}{l}2.517^{* * *} \\
(0.392)\end{array}$ & $\begin{array}{l}0.862 * * \\
(0.313)\end{array}$ & $\begin{array}{c}0.521 \\
(0.380)\end{array}$ \\
\hline Observations & 893 & 893 & 893 & 893 \\
\hline Log Likelihood & -540.002 & -540.019 & -540.002 & -540.019 \\
\hline Akaike Inf. Crit. & $1,112.004$ & $1,114.037$ & $1,112.004$ & $1,114.037$ \\
\hline
\end{tabular}

* $\mathrm{p}<0.1 ; * * \mathrm{p}<0.05 ; * * * \mathrm{p}<0.01$.

Proposition 38 is roughly half that of Proposition 30 (see Table 1). While the coefficient for the interaction term (Republican X low-income respondent) is significant for Proposition 38, the size of the interaction coefficient is roughly half the size (.38) compared to the Proposition 30 (.60) (see Table 3). Substantively, as shown in Figure 3B, a majority of low-income Republicans never approved of increasing taxes across the board (Proposition 38). For Proposition 30, the models estimate $55 \%$ of low-income
Republicans favored the initiative. And for Proposition 38 regardless of economic condition (low-income or evaluation of tax burden) a majority of Republicans never approved of the measure, unlike Proposition 30.

Figure $3 \mathrm{~B}$ also seems to suggest that low-income Republicans look a lot more like low-income Democrats in their probability of supporting Proposition 38, than they look like high income Republicans. The model suggests the failure to generate higher support across all 
Table 3. Predicting Voter Support for Proposition 30, Conditional Models

\begin{tabular}{|c|c|c|c|}
\hline & & endent variab & \\
\hline & & n Proposition & \\
\hline & (1) & $(2)$ & (3) \\
\hline Partisanship (Republican) & $-0.898 * * *$ & $-1.118 * * *$ & $-0.818 * * *$ \\
\hline & $(0.117)$ & $(0.124)$ & $(0.124)$ \\
\hline Perceive Tax Burden Too High & $-1.164 * * *$ & $-1.173 * * *$ & -0.004 \\
\hline & $(0.173)$ & $(0.173)$ & $(0.552)$ \\
\hline Income missing & 0.028 & 0.038 & 0.073 \\
\hline & $(0.283)$ & $(0.291)$ & $(0.288)$ \\
\hline High income (above 100K) & 1.008 & 0.190 & 0.241 \\
\hline & $(0.616)$ & $(0.215)$ & $(0.213)$ \\
\hline Low income (below 60K) & $0.507^{*}$ & -0.737 & $0.507^{*}$ \\
\hline & $(0.210)$ & $(0.534)$ & $(0.212)$ \\
\hline Services Better & -0.160 & -0.158 & -0.148 \\
\hline & $(0.093)$ & $(0.093)$ & $(0.092)$ \\
\hline Services Worse & -0.221 & -0.205 & -0.242 \\
\hline & $(0.178)$ & $(0.178)$ & $(0.178)$ \\
\hline Age & $-0.009 *$ & $-0.009 *$ & $-0.009 *$ \\
\hline & $(0.004)$ & $(0.005)$ & $(0.004)$ \\
\hline Education & 0.101 & 0.094 & 0.104 \\
\hline & $(0.076)$ & $(0.077)$ & $(0.076)$ \\
\hline Hispanic & 0.499* & $0.483^{*}$ & $0.495^{*}$ \\
\hline & $(0.238)$ & $(0.239)$ & $(0.240)$ \\
\hline African American & 0.610 & 0.600 & 0.584 \\
\hline & $(0.364)$ & $(0.364)$ & $(0.373)$ \\
\hline Asian & 0.313 & 0.310 & 0.282 \\
\hline & $(0.196)$ & $(0.196)$ & $(0.196)$ \\
\hline Married & 0.064 & 0.082 & 0.077 \\
\hline & $(0.173)$ & $(0.175)$ & $(0.174)$ \\
\hline Male & -0.106 & -0.111 & -0.106 \\
\hline & $(0.156)$ & $(0.157)$ & $(0.157)$ \\
\hline Partisanship X High income & -0.386 & & \\
\hline & $(0.273)$ & & \\
\hline Partisanship X Low income & & $0.607^{*}$ & \\
\hline & & $(0.242)$ & \\
\hline Partisanship X Perceive & & & \\
\hline Tax Burden Too High & & & -0.545 \\
\hline & & & $(0.242)$ \\
\hline Constant & $2.359 * * *$ & $2.848 * * *$ & $2.203^{* * *}$ \\
\hline & $(0.489)$ & $(0.503)$ & $(0.495)$ \\
\hline Observations & 893 & 893 & 893 \\
\hline Log Likelihood & -537.237 & -538.432 & -539.986 \\
\hline Akaike Inf. Crit. & $1,110.473$ & $1,112.863$ & $1,115.972$ \\
\hline
\end{tabular}

${ }^{*} \mathrm{p}<0.1 ;{ }^{* *} \mathrm{p}<0.05 ;{ }^{* * *} \mathrm{p}<0.01$.

groups is important. This illustrates one of our main points that how the tax policies are designed matters.

For a subset of lower income Republicans, selfinterest trumped partisanship favoring Proposition 30, but not Proposition 38. The same is true for low-income independents. The results show that economic selfinterest (i.e., income) conditions the effects of party in terms of raising taxes on the wealthy, but less so raising taxes on everyone. A key difference is that taxing the rich attracted support from low-income Republicans (and independents), and even independents who felt they paid too much in taxes, which did not occur for tax increases in general.

While it is common for observers to accuse lowerincome Republicans of acting against their own economic self-interest (e.g., Frank, 2005), from the same economic perspective, rich Democrats are also irrational, a charge that is leveled less frequently. In any case, when 
thinking about voting on an initiative, the views of the very wealthy are not that important for outcomes simply because there are so few wealthy, compared to poor and middle class, people.

\section{Conclusions}

The unique situation with competing tax increase proposals on the ballot in California in 2012 allowed us to directly examine how the structure of tax policies affects support for tax increases among different groups of voters, and consider the conditions under which partisanship and self-interest shape tax policy attitudes. Because we observe attitudes toward competing tax proposals from the same voters in the same election campaign we account for many individual and contextual factors that are hard to account for when comparing support for different tax proposals at different times or across different polities using observational data. The fact that the tax increases were structured very differently allowed us to determine how general opposition to tax increases rooted in partisanship and ideology may weaken and allow for individual self-interest to shape policy attitudes. We find that partisanship and selfinterest influence support for tax increases, but that the effect of party varies depending on one's income and the type of tax increase in question. Specifically, lowincome Republicans are more supportive of tax increases in general than high income Republicans, especially income tax increases on the wealthy, but less supportive of income tax increases on the lower and middle classes than Democrats with similar incomes. This indicates that self-interest can trump partisanship for this group of voters when the incidence of tax payment is clearly on other individuals, in this case the wealthy.

As Piketty and others propose high taxes on the wealthy to address growing inequality, and several members of the U.S. Congress and Democratic Presidential candidates have floated similar ideas, understanding how the structure of tax increases shapes support for different tax policy proposals is a salient question for policymakers. Just as California's passage of Proposition 13 in 1978 (which capped property taxes and made it harder to increase taxes) provided an example for other states wishing to reverse high taxes and rapidly growing government spending (Berkman, 1994), Proposition 30 may provide an example for other states wishing to increase government revenue and address income inequality.

\section{Conflict of Interests}

The authors declare no conflict of interests.

\section{References}

Abramowitz, A. I. (2018). The great alignment: Race, party transformation, and the rise of Donald Trump. New Haven, CT: Yale University Press.
Alesina, A., \& Angeletos, G. M. (2005). Fairness and redistribution. American Economic Review, 95(4), 960-980.

Alesina, A., Stantcheva, S., \& Teso, E. (2018). Intergenerational mobility and preferences for redistribution. American Economic Review, 108(2), 521-554.

Asatryan, Z., Baskaran, T., \& Heinemann, F. (2017). The effect of direct democracy on the level and structure of local taxes. Regional Science and Urban Economics, 65(1), 38-55.

Bartels, L. M. (2005). Homer gets a tax cut: Inequality and public policy in the American mind. Perspectives on Politics, 3(1), 15-31.

Bartels, L. M. (2008). Unequal democracy: The political economy of the new Gilded Age. Princeton, NJ: Princeton University Press.

Ballard-Rosa, C., Martin, L., \& Scheve, K. (2017). The structure of American income tax policy Preferences. The Journal of Politics, 79(1), 1-16.

Benabou, R., \& Ok, E. A. (2001). Social mobility and the demand for redistribution: The POUM hypothesis. The Quarterly Journal of Economics, 116(2), 447-487.

Berkman, M. B. (1994). The state roots of national politics: Congress and the tax agenda, 1978-1986. Pittsburgh, PA: University of Pittsburgh Press.

Boudreau, C., \& MacKenzie, S. A. (2018). Wanting what is fair: How party cues and information about income inequality affect public support for taxes. The Journal of Politics, 80(2), 367-381.

Bowler, S., \& Donovan, T. (1998). Demanding choices: Opinion, voting, and direct democracy. Ann Arbor, $\mathrm{Ml}$ : University of Michigan Press.

Bowler, S., \& Donovan, T. (2004). Measuring the effect of direct democracy on state policy: Not all initiatives are created equal. State Politics and Policy Quarterly, 4, 345-363.

Bowler, S., Donovan, T., \& Tolbert, C. J. (Eds.). (1998). Citizens as legislators: Direct democracy in the United States. Columbus, $\mathrm{OH}$ : Ohio State University Press.

Branton, R. P. (2003). Examining individual-level voting behavior on state ballot propositions. Political Research Quarterly, 56(3), 367-377.

Broockman, D. E., \& Butler, D. M. (2017) The causal effects of elite position-taking on voter attitudes: Field experiments with elite communication. American Journal of Political Science, 61(1), 208-221.

Broockman, D. E., \& Skovron, C. (2018). Bias in perceptions of public opinion among political elites. American Political Science Review, 112(3), 542-563.

Buchanan, W. (2012). Big biz joins Gov. Jerry Brown in SF for Prop. 30 push. San Francisco Chronicle.

Burnett, C. M. (2013). Does campaign spending help voters learn about ballot measures? Electoral Studies, 32(1), 78-89.

Campbell, A., Converse, P. E., Miller, W. E., \& Stokes, D. E. (1960). The American voter. Chicago, IL: University of Chicago Press. 
Claassen, C., Tucker, P., \& Smith, S. S. (2015). Ideological labels in America. Political Behavior, 37(2), 253-278.

D-Lab. (n.d.). California polls. D-Lab. Retrieved from https://dlab.berkeley.edu/data-resources/californiapolls

Dutton, S. (2012). Polls show longtime support for tax hikes on the rich. CBS News.

Ellis, C., \& Stimson, J. A. (2012). Ideology in America. Cambridge: Cambridge University Press.

Enns, P., Kelly, K. N. J., Morgan, J., Volscho, T., \& Witko, C. (2014). Conditional status quo bias and top income shares: How U.S. political institutions have benefited the rich. Journal of Politics, 76(2), 289-303.

Frank, T. (2005). What's the matter with Kansas? New York, NY: Holt Publishers.

Franko, W., Tolbert, C. J., \& Witko, C. (2013). Inequality, self-interest and public support for 'Robin Hood' tax policies. Political Research Quarterly, 66(4), 923-937.

Franko, W., \& Witko, C. (2017). The new economic populism: How states respond to economic inequality. Oxford: Oxford University Press.

Gerber, E. R. (1999). The populist paradox: Interest group influence and the promise of direct legislation. Princeton, NJ: Princeton University Press.

Gilens, M. (2012). Affluence and influence: Economic inequality and political power in America. Princeton, NJ: Princeton University Press.

Green, D., Palmquist, B., \& Schickler, E. (2004). Partisan hearts and minds. New Haven, CT: Yale University Press.

Grossman, M., \& Hopkins, D. (2016). Asymmetric politics: Ideological Republicans and group interest Democrats. Oxford: Oxford University Press.

Hennighausen, T., \& Heinemann, F. (2015). Don't tax me? Determinants of individual attitudes toward progressive taxation. German Economic Review, 16(3), 255-289.

Hertel-Fernandez, A., Mildenberger, M., \& Stokes, L. C. (2019). Legislative staff and representation in Congress. American Political Science Review, 113(1), 1-18.

Jaccard, J., \& Turrisi, R. (2003). Interaction effects in multivariate regression. Thousand Oaks, CA: Sage Publications.

Kelly, N. J., \& Enns, P. K. (2010). Inequality and the dynamics of public opinion: The self-reinforcing link between economic inequality and mass preferences. The American Journal of Political Science, 54(4), 855-870.

Kelly, N. J., \& Witko, C. (2012). Federalism and American inequality. The Journal of Politics, 74(2), 414-426.

Kogan, V. (2016). Do anti-union policies increase inequality? Evidence from state adoption of right-towork laws. State Politics and Policy Quarterly, 17(2), 180-200.

Kristof, N. (2014). An idiot's guide to inequality. The New York Times. Retrieved from https://www. nytimes.com/2014/07/24/opinion/nicholas-kristofidiots-guide-to-inequality-piketty-capital.html

KCET. (2012). Ballot brief: Proposition 2012 cheat sheet: California's November 6th election. Retrieved from https://www.kcet.org/ballot-brief/proposition2012-cheat-sheet-californias-nov-6-election

Lenz, G. (2009). Learning and opinion change, not priming: Reconsidering the priming hypothesis. American Journal of Political Science, 53(4), 821-837.

Lupia, A. (1994). Shortcuts versus encyclopedias: Information and voting behavior in California insurance reform elections. American Political Science Review, 88(1), 63-76.

Lupia, A., Levine, A. S., Menning, J. O., \& Sin, G. (2007). Were Bush tax cut supporters 'simply ignorant?' A second look at conservatives and liberals in 'Homer gets a tax cut'. Perspectives on Politics, 5(4), 773-784.

Mason, L. (2018). Uncivil agreement: How politics became our identity. Chicago, IL: University of Chicago Press.

Matsusaka, J. (2004). For the many or the few: The initiative, public policy, and American democracy. Chicago, IL: University of Chicago Press.

McCall, L., \& Kenworthy, L. (2009). Americans' social policy preferences in the era of rising inequality. Perspectives on Politics, 7(3), 459-484.

Meltzer, A. H., \& Richard, S. F. (1981). A rational theory of the size of government. Journal of Political Economy, 89(5), 914-927.

Nicholson, S. P. (2005). Voting the agenda: Candidates, elections, and ballot propositions. Princeton, NJ: Princeton University Press.

Page, B. I., Bartels, L. M., \& Seawright, J. (2013). Democracy and the policy preferences of wealthy Americans. Perspectives on Politics, 11(1), 51-73.

Pew Research Center. (2017). Most see inequality growing, but partisans differ over solutions. Pew Research Center. Retrieved from http://www.peoplepress.org/2014/01/23/most-see-inequalitygrowing-but-partisans-differ-over-solutions

Piketty, T. (1995). Social mobility and redistributive politics. The Quarterly Journal Economics, 110(3), 551-584.

Piketty, T. (2014). Capital in the 21st Century. Cambridge, MA: Belknap Press.

Roberts, M. L., Hite, P. A., \& Bradley, C. F. (1994). Understanding attitudes toward progressive taxation. Public Opinion Quarterly, 58(2), 165-190.

Sears, D. O., Citrin, J. (1982). Tax revolt: Something for nothing in California. Cambridge, MA: Harvard University Press.

Sides, J., \& Citrin, J. (2007). European opinion about Immigration: The role of identities, interests and information. British Journal of Political Science, 37(3), 477-504.

Slemrod, J. (2006). The role of misconceptions in support for regressive tax reform. National Tax Journal, 2006, 57-75. 
Smith, D. A, \& Tolbert, C. J. (2001). The initiative to party: Partisanship and ballot initiatives in California. Party Politics, 7(6), 739-757.

Tolbert, C. J., \& Hero, R. E. (1996). Race/ethnicity and direct democracy: An analysis of California's illegal immigration initiative. Journal of Politics, 58(3), 806-818.

Tuxhorn, K. L., D’Attoma, J. W., \& Steinmo, S. (2019). Trust in institutions: Narrowing the ideological gap over the federal budget. Journal of Behavioral Public Administration, 2(1).
Volscho, T., \& Kelly, N. J. (2012). The rise of the super-rich: Power resources, taxes, financial markets, and the dynamics of the top 1 Percent, 1949 to 2008. American Sociological Review, 77(5), 679-699.

Witko, C. (2017). Upper class bias and class conflict in America. The Forum, 15(1), 127-149.

Yglesias, M. (2019). Taxing the rich is very popular; it's Republicans who have the radical position. Vox. Retrieved from https://www.vox.com/policy-andpolitics/2019/1/8/18171932/tax-public-opinionalexandria-ocasio-cortez

\section{About the Authors}

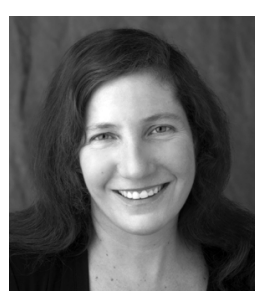

Caroline J. Tolbert's research weaves together a concern with politics and inequality, elections and representation, and state and local politics/policy. She has contributed to many subfields including technology policy and digital politics, direct democracy, voting and elections, electoral systems and race and politics. She is coauthor of Digital Cities: The Internet and the Geography of Opportunity (2012), Oxford University Press.

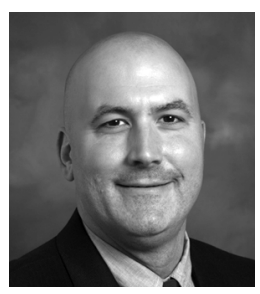

Christopher Witko's research focuses on how public policies shape and respond to economic outcomes like inequality, mobility and unemployment, and the role of the public and organized interests in shaping public policy. His book The New Economic Populism: How States Respond to Economic Inequality (Oxford) won the State Politics and Policy Section's Virginia Gray best book award in 2018.

Cary Wolbers earned his Ph.D. in 2018 from the University of Nebraska with emphasis in U.S. voting and elections. His research is focused on preferential voting, ranked choice and instant runoff voting. Wolbers works as a data engineer and data scientist in the private sector but continues to pursue academic research. 